\title{
架空配電線用のロープ牽引装置の登坂能力向上に関する研究
}

\author{
武 本 純 平*1 於 保 健 一*1 小林 竜 一*1 \\ 大田和健*1 坪 内 孝 司*2
}

\section{Study on Improvement of Driving Performance of Rope Traction Device used on Overhead Distribution Lines}

\author{
Jumpei Takemoto*1, Kenichi Oho*1, Ryoichi Kobayashi*1, \\ Takeshi Ootawa*1 and Takashi Tsubouchi*2
}

\begin{abstract}
As for the procedure of replacing the cable for overhead distribution lines, methods without laying the construction rope on the road are required. It is expected to utilize a rope traction device (RTD) as one of the methods. But in some cases, this method cannot be conducted due to the lack of driving performance of RTD. So we focused on the improvement of the driving performance of RTD used on the distribution lines. We observed the behavior of the moving RTD and modeled RTD moving on the cable of the distribution lines while towing the rope. Using the model, we showed the effect of improving the driving performance by pressing force between wheels of RTD and the cable. The validity of the pressing force was shown in the experiment.
\end{abstract}

Key Words: Overhead Distribution Lines, Rope Traction Device, Moving Performance

\section{1.は じめ に}

架空配電線路は電力系統末端の電路であり, 需要家の近くに 位置している．最大印加電圧 $6.6[\mathrm{kV}]$, 電柱の高さ $10[\mathrm{~m}]$ 程度, 電柱の設置間隔（径間）は平均 $30[\mathrm{~m}]$ 程度である。電線は導体 に絶縁性のゴムを被覆した構造をして㧍り，絶縁支持材を介し て電柱に架けられている。 その電線の勾配は，電柱に近づくに つれ増加し，特に径間が大きい場合や電柱の設置場所に高低差 がある場合は，45 [deg] に達するケースもある。

このような架空配電線路では, 落雷による損傷や経年による 劣化, 電力系統網の再構築などのため, 定期的に電線の架け替 えが行われている。この電線架け替え工事ではロープを使った 工法が用いられている。まず径間にロープを渡し，ロープの一 端に新しい電線を結び付け，そのロープの他端を手繰り寄せる ことで電柱間に新しい電線を架ける工法である。ロープを電柱 間に渡す方法はいくつかある [1] [2]. 筆者らはこの目的のため にロープ杽引装置（以下，RTD: Rope Traction Device）も実 用化しており，これを活用している。ロープを取り付けたRTD を既設電線に懸垂させ，既設電線上を移動させることにより， ロープを電柱間に渡すことができる（Fig. 1 参照）.

しかし, 現行の RTD の電線傾斜部を登る能力（以下, 登坂能 力）は，実現場で使用した経験上 $15 \sim 30[\mathrm{deg}]$ 程度である。こ

原稿受付 2020 年 11 月 6 日

${ }^{* 1}$ 株式会社関電工

*2 筑波大学大学院 システム情報工学研究科

${ }^{* 1}$ Kandenko Company, Limited

${ }^{* 2}$ Graduate School of Systems and Information Engineering, University of Tsukuba

一本論文は有用性（システム設計・構築分野）で評価されました。

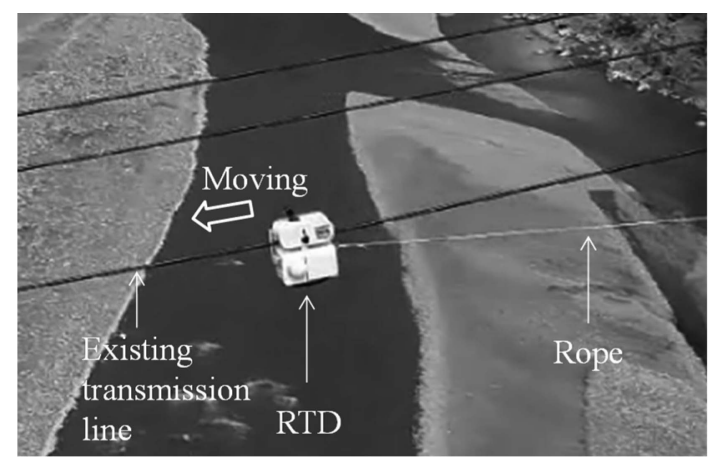

Fig. 1 RTD used on overhead distribution lines

のため,この RTD は目的の電柱にたどり着けず，作業の中断 を余儀なくされるケースがあり，その登坂能力の不足が指摘さ れている，そこで本研究では，RTD を用いた架空配電線路の電 線架け替え工事を確実に行えるように, 最大登坂角度 45 [deg] を有するRTD の開発を目標とする.

開発に当たっては，RTD には十分な登坂能力と合わせて小 型軽量であることが求められる. RTD は高所で扱われること, 電線に極力荷重を掛けないこと，作業員の負担を軽減する観点 から, 小型軽量が望ましく, 圥長な機構は避けるべきである. RTD は高所作業車のバケットに乗せられ高所の電線まで運ば れることになる。 バケットの寸法は, 幅 $1,010[\mathrm{~mm}] \times$ 奥行き $710[\mathrm{~mm}]$ である。この中に作業員 1 名が乗り达み, 各種工具 が納められている。 バケット内の RTD を置けるスペースは幅 $300[\mathrm{~mm}] \times 300[\mathrm{~mm}]$ 程度となる．また，高所であること，作 業員への負担軽減から，RTD には軽く扱いやすいことが求めら れる.このため, RTD の重さを $5[\mathrm{~kg}]$ に設定した. 
これまで, 架空送電線路の点検作業用として電線上を移動可 能な装置についての報告はあるが [3], 架空配電線路の電線架け 替え作業に使用する RTD に関する研究についての報告はない. また文献 [4] では, 装置の最大登坂角度として 30 [deg] を設定し ているが，筆者らの知るところでは同種の装置で $45[\mathrm{deg}]$ を想 定した移動機構の検討についての報告はない。そこで本稿では, 今後の RTD の登坂能力の向上に資するため，まず，1. 現行の RTD の登坂の様子を観察しその挙動を調べ，2. 現行の RTD の モデル化を行い，3. そのモデルから理論的な登坂限界を示す. そして，4. 登坂能力を向上させる方法として，押付力の付与を 提案し, その妥当性を実験で示す.

本稿の構成は以下のとおりである. 2 章では, 現行の RTD に ついて登坂時の状況を観察した結果について述べる．3 章では， RTD のモデル化と登坂限界について述べる，4 章では，登坂能 力を向上させる方法として押付力の付与を提案し, 実験により その妥当性を示す. 5 章でまとめと今後の課題について述べる.

\section{2. 登坂時の RTD の観察}

現行の RTD の構造と仕様を Fig. 2 と Table 1 に示す. 現 行の RTD は二つの車輪を有し，車輪形状は鼓型である．この 車輪の凹み部を電線に乗せることで RTD が電線を線路として 懸垂できる，RTDの自重により車輪が電線に押し付けられる ことで車輪と電線間に摩擦力が生じ, それを利用して推進力を

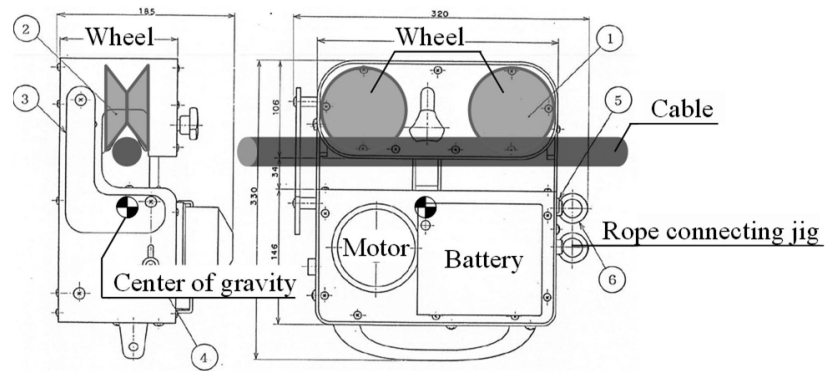

Fig. 2 Conventional RTD

Table 1 Specifications of conventional RTD

\begin{tabular}{ll}
\hline \multicolumn{1}{c}{ Components } & \multicolumn{1}{c}{ Specifications } \\
\hline Body cover & Vinyl resin \\
\hline Wheel & Urethane rubber \\
\hline Withstand voltage $[\mathrm{V}]$ & 6,600 \\
\hline Weight $[\mathrm{kg}]$ & 6.7 \\
\hline Size $[\mathrm{mm}]$ & $\mathrm{L}: 320, \mathrm{~W}: 165, \mathrm{H}: 330$ \\
\hline
\end{tabular}

得る.

ロープを牽引しない状態で, 現行の RTD の登坂の様子を観察し たところ, 電線の勾配が $30[\mathrm{deg}]$ を超えたあたりから, 電線の勾配 と現行の RTD の傾きに差が生じる現象が確認された (Fig. $3(\mathrm{a})$ 参照)。このとき後輪は電線から離れており (Fig. 3 (b) 参照), 前輪のみが電線と接している状態であった。この状態に至った 後，登坂限界に至ることを確認した，電線に接触する車輪が一 つになったため接触面積も半減し，グリップカが不足したと推 察される。

後輪が電線から離れる現象について定性的に検討する. Fig. 4 に現行の RTD 内部の機構と電線の幾何学的配置を示す. 図中に は，電線イメージと前輪を通る鉛直線を載せている. Fig. 4 (a) は現行の RTD を水平に置いた状態を表す。前輪と重心を結ぶ 線分と，鉛直線との成す角度 $\delta$ は 33 [deg] である. Fig. 4 (b) は 電線勾配 $\theta$ を $\delta$ と同じ角度 $(\theta=\delta)$ にした場合, Fig. $4(\mathrm{c})$ は $\delta$ より大きな角度 $(\theta>\delta)$ にした場合を表す.ここで，力と モーメントはつり合っていると仮定する. Fig. 4 (b) では, 前輪 が作用点となり，その作用点を通る鉛直線上に重心が位置して いる. このとき, 後輪が電線から受ける垂直抗力はゼロとなる. Fig. 4 (c) に示すように, 電線勾配 $\theta$ が増しても重心は作用点で ある前輪を通る鉛直線上に位置し続ける。その結果，観察され たように後輪は電線から離れる現象が生じると考えられる.

このことは, 直感的には, $\delta$ が大きくなれば, 後輪が電線か ら離れる角度は高角度になり, 登坂能力が向上すると考えられ る.そのため, 重心の移動（後方もしくは上方）や前後輪の間 隔の拡大の対策が考えられる。この対策は RTD 内部の機構の 煩雑さ，機体の大型化・重量化を招き，実用性を著しく損なう 恐れがある。

\section{3. 現行の RTD のモデル化}

\subsection{RTD に作用するロープの張力}

まず，今津らが提案したへリコプタとそれが吊るしたケーブル

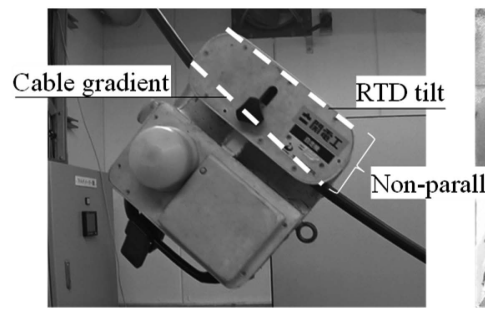

(a)

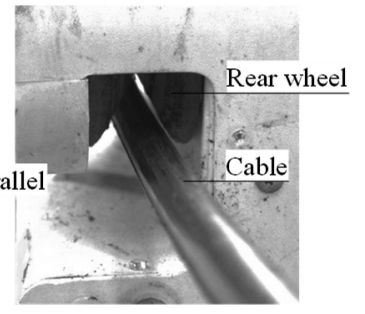

(b)
Fig. 3 (a) RTD tilt is different from the cable gradient over 30 degrees, (b) The rear wheel of RTD away from the cable

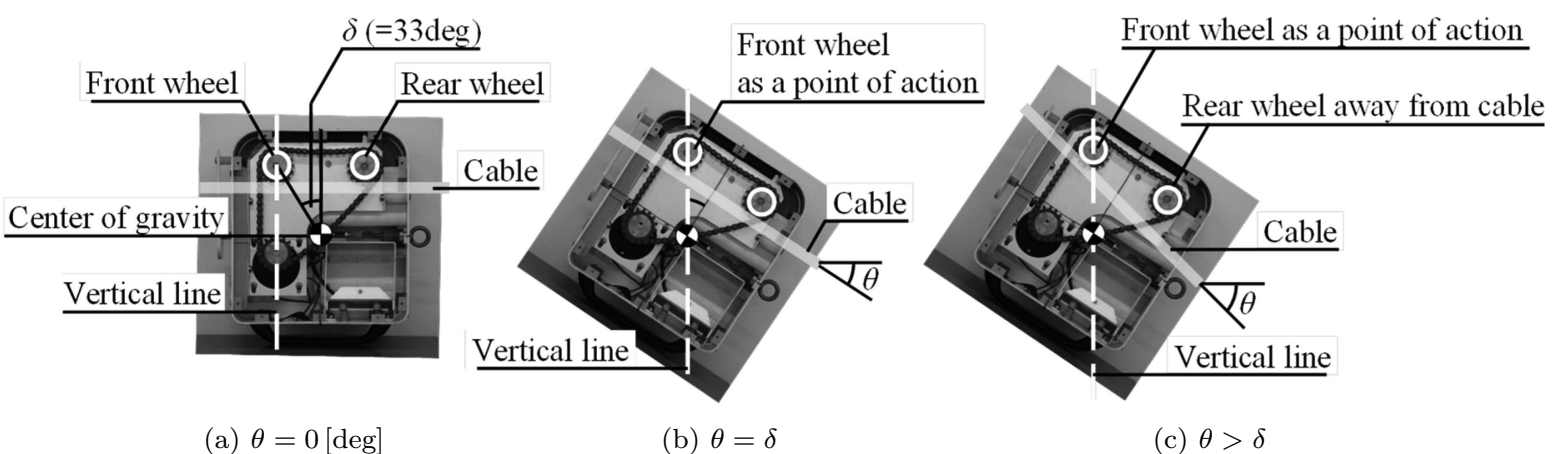

Fig. 4 Geometric arrangement of mechanism inside RTD and cable 


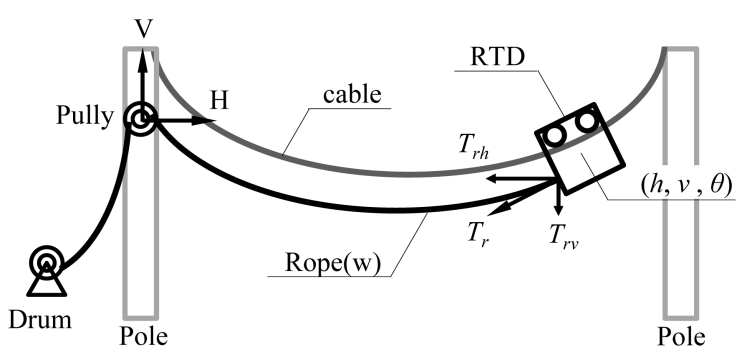

Fig. 5 Schematic drawing of the rope work with RTD

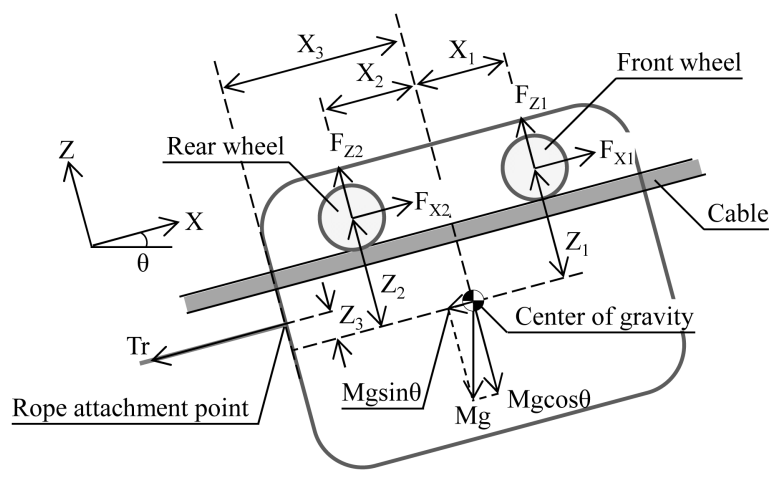

\begin{tabular}{cl}
\hline$\theta$ & Cable gradient \\
\hline$M g$ & RTD's own weight \\
\hline$T_{r}$ & Force acting on RTD from a rope \\
\hline$j=$ & Subscripts that indicate the front wheel, the rear \\
$1,2,3$ & wheel and the rope attachment point respectively \\
\hline $\mathrm{X}_{\mathrm{j}}$, & Coordinate position with the center of gravity as \\
$\mathrm{Z}_{\mathrm{j}}$ & the origin \\
\hline$F_{z j}$ & Normal drag that the wheel receives from the cable \\
\hline$F_{x j}$ & Driving force of the wheel \\
\hline
\end{tabular}

Fig. 6 RTD model moving on a cable with slope

の張力の算出法 [5] を参考にし, その手法に則って, RTD に作用 するロープの張力を導出する. Fig. 5 にRTD を用いたロープ 架線作業における座標系と変数，力のつり合いを示す．滑車位 置を原点とし, 水平方向を $\mathrm{H}$ 軸，鉛直上向き方向を $\mathrm{V}$ 軸, RTD の位置と角度を $(h, v, \theta)$, ロープの単位長さ当たりの質量を $w$ と置く、ロープから RTDに $T_{r}$ が作用した場合， $T_{r}$ の水平 分力 $T_{r h}$ は式 $(1)$ で, 鉛直分力 $T_{r v}$ は式 $(2)$ で, $T_{r}$ は式 (3) で表すことができる.

$$
\begin{gathered}
T_{r h}=C w g \\
T_{r v}=w g \sin h\left(\frac{h-h_{v}}{C}\right) \\
T_{r}=\sqrt{T_{r h}^{2}+T_{r v}^{2}}
\end{gathered}
$$

ここで, $C$ はロープのたるみ度合いを表すカテナリ数， $h_{v}$ は ロープ最下点の $\mathrm{H}$ 座標, $g$ は重力加速度とする，また， RTD を 懸垂させても電線のたるみは変化しないと仮定する.

\subsection{RTD のモデル化}

2 章で述べた内容について具体的に RTD のモデルをたてて 考察する. 登坂時の現行の RTD のモデルを Fig. 6 に示す. 電 線と地面の成す角度を電線勾配とし， $\theta$ で表す。電線に沿う方 向を X 方向，電線に垂直な方向を Z 方向とする. 自重を $M g$ と する. 重心は電線下方に位置する. 前輪と後輪, ロープ取付箇

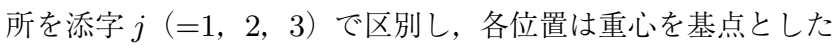

$\mathrm{X}$ 方向と $\mathrm{Z}$ 方向の位置 $\left(X_{j}, Z_{j}\right)$ で表す。車輪が電線から受け る垂直抗力を $F_{Z j}$, 車輪の駆動力を $F_{X j}$ とする. 車輪表面と電 線表面は硬く一様であると見なし，モデルでは車輪の転がり抵 抗は小さいとして無視する. また RTD は走行中急加速や急減 速をしないため, モータや車輪の反トルクは小さいとして無視 する，ロープから RTD に作用する力の大きさを $T_{r}$ とする．牽 引されるロープは他系統電線に接触しないように電線のたるみ に沿って配線されるため, $T_{r}$ の向きは $\theta$ と平行であるとする.

\section{3 登坂限界}

モータトルクは十分大きいと仮定すると, 車輪に生じる駆動 力は車輪と電線間の静止摩擦係数と車輪が電線から受ける垂直 抗力の積で表すことができる，静的な状態では，その垂直抗力 は自重の電線に垂直な分力とつり合うことから, 式 (4) を満 たす。

$$
F_{X 1}+F_{X 2}=\mu F_{Z 1}+\mu F_{Z 2}=\mu M g \cos \theta
$$

ここで， $\mu$ は車輪と電線間の静止摩擦係数を表す。電線に沿い 進行方向とは逆向きに生じる力を牽引負荷とし, $M g \sin \theta+T_{r}$ と定義する．杽引負荷に対して前後輪の駆動力の和が大きい場 合（式（5）参照), RTD は登坂可能となる.

$$
M g \sin \theta+T_{r}<\mu M g \cos \theta
$$

RTD の移動に伴い $\theta$ と $T_{r}$ が増加すると, 牽引負荷も増加し, 駆動力は減少する。 やがて, 牽引負荷と駆動力がつり合い（式 (6) 参照), 登坂限界に至る.

$$
M g \sin \theta_{\max }+T_{r}=\mu M g \cos \theta_{\max }
$$

ここで $\theta_{\max }$ は登坂限界角度を表す. 式 (6) から, RTD の登坂 能力（すなわち登坂限界角度 $\theta_{\max }$ ）は， $T_{r}, \mu, M g$ に支配さ れることが分かる. 一方, 重心を基点としたモーメントのつり 合いは式 (7) で, 前後輪が電線から受ける垂直抗力 $F_{Z 1}, F_{Z 2}$ とその和 $F_{Z 1}+F_{Z 2}$ は，それぞれ式 $(8) \sim(10)$ で表すことが できる。

$$
\begin{aligned}
X_{1} F_{Z 1}+ & Z_{3} T_{r}=X_{2} F_{Z 2}+Z_{1} F_{X 1}+Z_{2} F_{X 2} \\
F_{Z 1}= & \frac{X_{2}+\mu Z_{2}}{X_{1}+X_{2}+\mu\left(Z_{2}-Z_{1}\right)} M g \cos \theta \\
& -\frac{Z_{3}}{X_{1}+X_{2}+\mu\left(Z_{2}-Z_{1}\right)} T_{r} \\
F_{Z 2}= & \frac{X_{1}-\mu Z_{1}}{X_{1}+X_{2}+\mu\left(Z_{2}-Z_{1}\right)} M g \cos \theta \\
& +\frac{Z_{3}}{X_{1}+X_{2}+\mu\left(Z_{2}-Z_{1}\right)} T_{r} \\
& F_{Z 1}+F_{Z 2}=M g \cos \theta
\end{aligned}
$$

\section{4 モデルの妥当性の評価}

Fig. 7 に, $T_{r}$ と $\theta_{\max }$ の関係における実験結果と理論曲線の 比較を示す，実験は，実機，電線仕上り外径 $18.6[\mathrm{~mm}]$, 電線表 面は乾燥状態で行った. 実験結果に扔ける $T_{r}$ と $\theta_{\max }$ の関係は, 最小二乗法により傾き -0.73 , 切片 37.9 の直線で表すことがで き, Fig. 7 中の破線となる.一方，理論值は式（6）に基づき，そ の条件は $M=6.7[\mathrm{~kg}]$ (現行の RTD と同じ重量), $\mu=0.76$ と する.この場合の $T_{r}$ と $\theta_{\max }$ の関係は, 傾き -0.72 , 切片 37.6 の直線で表すことができ, Fig. 7 中の実線となる. Fig. 7 に示 すように, 2 本の直線はよく一致しており, 車輪と電線間の静 止摩擦係数 $\mu$ の值は 0.76 付近であると言える. 


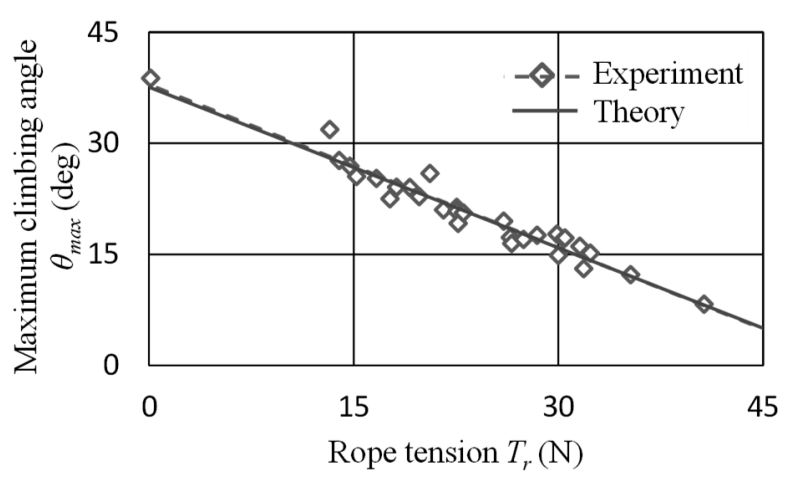

Fig. 7 Comparison between experimental results and a theoretical curve on the relationship between $T_{r}$ and $\theta_{\max }$

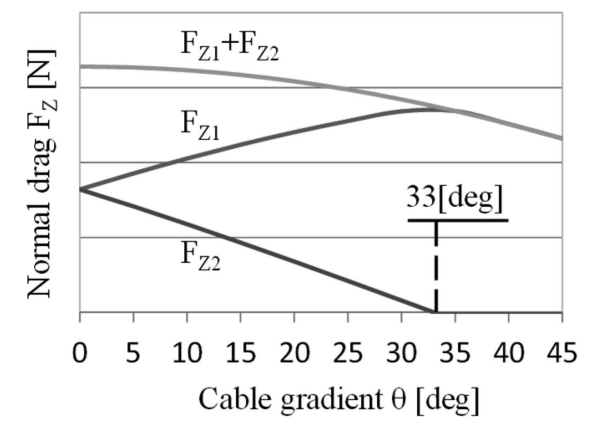

Fig. 8 Relationship between the cable gradient $\theta$ and each Normal drag $F_{Z 1}, F_{Z 2}, F_{Z 1}+F_{Z 2}$ for the conventional RTD

また，現行の RTD において式（8)〜（10）に示す車輪が電線 から受ける垂直抗力 $F_{Z 1}, F_{Z 2}, F_{Z 1}+F_{Z 2}$ と電線勾配 $\theta$ との 関係を Fig. 8 に示す。電線勾配 $\theta$ の増加に伴い，後輪が電線か ら受ける垂直抗力 $F_{Z 2}$ は減少し， $\theta=33$ [deg] でゼロに至る. これは，2 章で述べた観察結果と整合が取れている.

以上の結果から，モデルの妥当性は示されていると言える.

な打仮定として, 式 (9)に打いて $F_{z}=0$ となる角度を 40 [deg], $45[\mathrm{deg}]$ とするためには，前後輪の間隔を 1.29 倍， 1.54 倍と拡 大する必要がある。

\section{4. 押付力の付与による登坂能力の向上}

\section{1 定性的検討}

移動ロボットの登坂能力を決定付ける要因として, Trafficability 限界がある. 文献 [6]によると, これは車輪と路面（本件 では電線が該当する）の関係によって生じる限界を意味し，一 例として「車輪と電線間の摩擦係数や押付力が弱いため, 十分 な駆動力を発揮できず, 登坂が制限される」現象が挙げられる. 前章で観察された後輪が電線から離れることにより十分な駆動 力を発揮できない現象が，このケースに該当する.

そこで今回は，登坂能力の向上のため車輪と電線間に押付力 を付与する方法に着目する. その押付力を $P$ で表す. $P$ の付与 は車輪が電線から受ける垂直抗力に寄与することから, 式 (6) を式（11）に変更できる.

$$
M g \sin \theta_{\max }+T_{r}=\mu M g \cos \theta_{\max }+\mu P
$$

ここで, 式 (11）の左辺は牽引負荷, 右辺は駆動力である. 式 （11）に基づいた $P$ による $\theta_{\max }$ の変化を表した模式図を Fig. 9 に示す。図中の丸印で示した駆動力と牽引負荷との交点におけ る電線勾配が $\theta_{\max }$ となる，P 増すことで牽引負荷を維持し たまま駆動力のみ増やすことができるため, 結果 $\theta_{\max }$ は増加

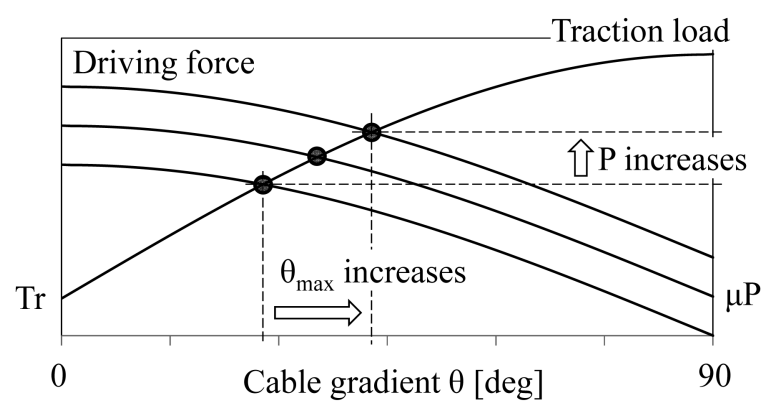

Fig. 9 Increase of the movable limit angle $\theta_{\max }$ due to increase of $\mathrm{P}$

する.

\section{2 実証試験}

前述した押付力の付与の登坂能力向上への効果を実験的に検 証する.

4. 2.1 滑り率

本実験では，文献 [7] を参考に，登坂能力を評価する尺度とし て滑り率 $\lambda$ を用いる。滑り率 $\lambda$ は車輪回転速度 $r \omega$ と車輪移動 速度 $V_{\omega}$ の差を無次元化した量である.ここで $r$ は車輪半径， $\omega$ は車輪角速度である。本実験では駆動モー夕の回転数から得る 距離 $L_{1}$ と実移動距離計測用の受動輪の回転数から得る距離 $L_{2}$ の比と定義する（式 (12) 参照).

$$
\lambda=\frac{r \omega-V_{\omega}}{r \omega}=\frac{L_{1}-L_{2}}{L_{1}}
$$

\section{2 .2 試験体と計測器}

本実験では押付力の登坂能力への効果を検証するため，試験 体の自重と電線の勾配に影響されない押付力が求められる. そ こで，Fig. 10 に示す試験体を製作した. Fig. 10 (a) に示すよ うに試験体は二つのガイドローラと 2 対の駆動輪を有している. また Fig. 10 (b) に示すように，試験体の自重はガイドローラを 介して電線で支持し，駆動輪は試験体の自重が掛からないよう に電線の左右に配置し，スライドレールにより滑らかに摺動可 能とし，バネ力により電線を左右で挟み込み押さえ付ける機構 とした.

試験体の仕様を Table 2 に示す.ガイドローラや駆動輪が 電線と接触した際，電線を傷付けないように，それらの硬度は， いずれも電線の絶縁被覆より低い值（ショア60）を選定した. バネ力の調整は使用本数やバネ定数を変えることで可能とした. 本実験では，バネ本数 4 本または 6 本，バネ定数 $0.7[\mathrm{~N} / \mathrm{mm}]$ を採用した。架空配電線路で一般に使用される電線（仕上り外 径 $18.6[\mathrm{~mm}]$ ） を対となる駆動輪の間に設置した場合，バネの 伸びは $12[\mathrm{~mm}]$ となる.このため, 押付力は計算上 $33.6[\mathrm{~N}]$ と $50.4[\mathrm{~N}]$ となる.

試験体は，Fig. 11 に示すように，モータ回転数を計測する ためのエンコーダを機体に内包し，前方に実移動距離を計測す るための受動輪と, その回転数を計測するためのエンコーダを 設置し，上部に試験体の傾きを計測するための傾斜センサ，後 部にロープの張力を計測するための張力計, 下部に電圧電流計 やコンバータを取り付けた。電源は商用系統から試験体に常時 供給可能とした．各計測器で得られたデータは有線により PC に送り保存した.

\section{2 .3 実験環境}

Fig. 12 は実験の様子である. 実環境で一般に使用されてい る仕上り外径 $18.6[\mathrm{~mm}]$ の電線を用意し, 設置間隔 $6[\mathrm{~m}]$ の電 


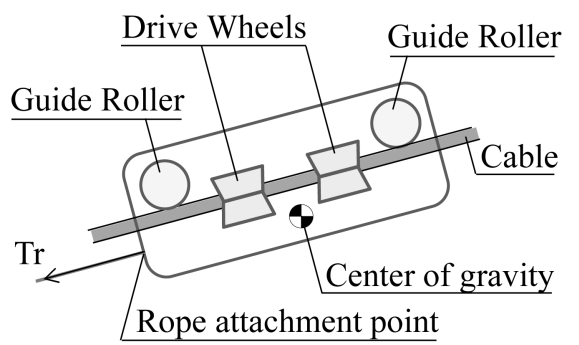

(a)

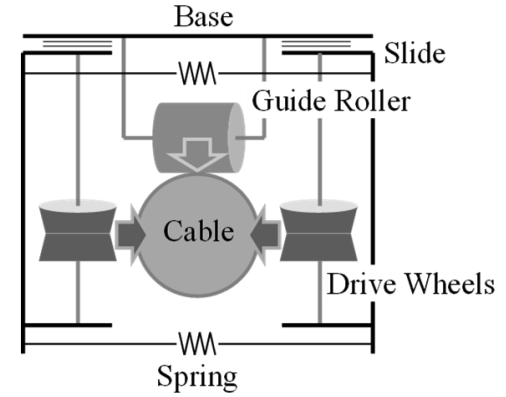

(b)

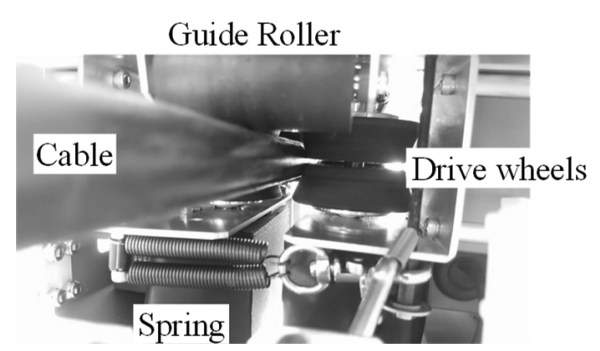

(c)

Fig. 10 Internal structure of the test equipment (a) Image side view (b) Image cross section (c) Actual object

Table 2 Specifications of test equipment

\begin{tabular}{|c|c|}
\hline Components & Specifications \\
\hline Guide Roller & $\begin{array}{l}\text { Arrangement : Front and rear, } \\
\text { Type : Cylindrical, } \\
\text { Material : Urethane rubber, } \\
\text { Hardness : shore } 60 \text {, Number : } 2 \text { pieces }\end{array}$ \\
\hline Slide & Linear rail \\
\hline Drive Wheel & $\begin{array}{l}\text { Arrangement : Left and right, } \\
\text { Type : V, Material : CR, } \\
\text { Hardness : shore } 60, \quad \text { Number }: 4 \text { pieces }\end{array}$ \\
\hline Spring & $\begin{array}{l}\text { Arrangement : Front, rear, top and bottom, } \\
\text { Spring constant : } 0.7[\mathrm{~N} / \mathrm{mm}] \\
\text { Pressing force : } 33.6[\mathrm{~N}], 50.4[\mathrm{~N}] \\
\text { Number : } 4 \text { and } 6 \text { pieces }\end{array}$ \\
\hline Weight & $5[\mathrm{~kg}](7.75[\mathrm{~kg}]:$ Including measurements $)$ \\
\hline Size & $\mathrm{L}: 385[\mathrm{~mm}], \mathrm{W}: 200[\mathrm{~mm}], \mathrm{H}: 163[\mathrm{~mm}]$ \\
\hline
\end{tabular}

柱の間に, 張力 $3[\mathrm{kN}]$, 架線角度 $0,15,30,45[\mathrm{deg}]$ で, 電圧 を印加せずに架線する。電線に取り付けた試験体の後部に，実 際工事で使用されている直径 $1[\mathrm{~cm}]$, 重さ $49[\mathrm{~g} / \mathrm{m}]$ の撚り状の ロープ (Fig. 13 参照) を取り付ける。 そのロープに同電線に 取り付けた滑車を介しておもりを吊り下げる，おもりの重さは

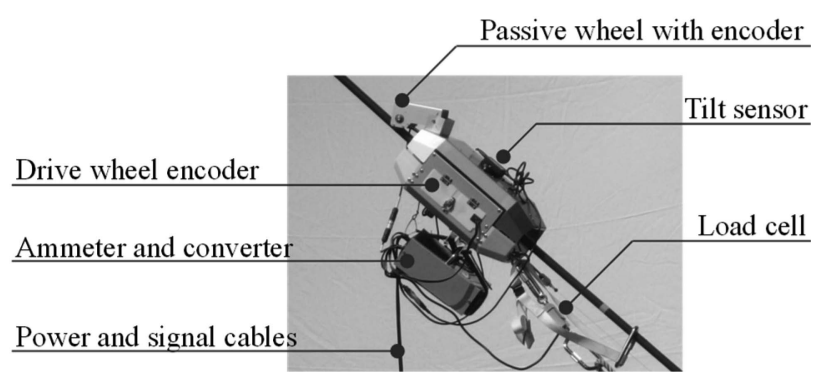

Fig. 11 A test equipment with measurements

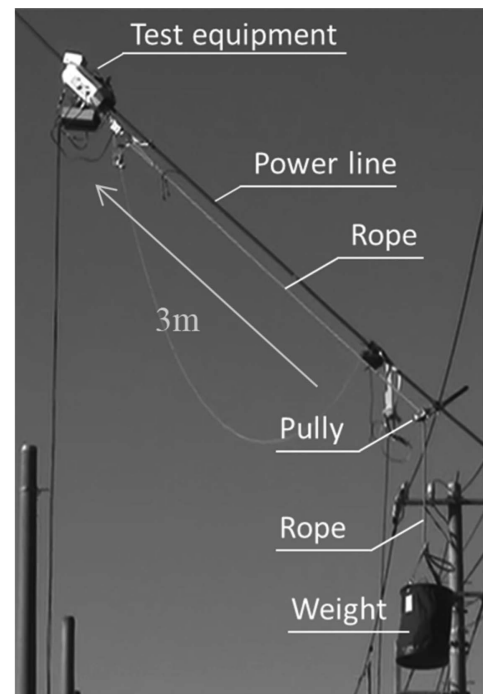

Fig. 12 Demonstration test

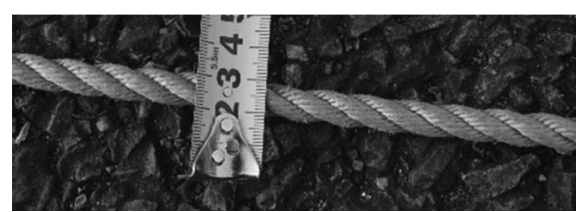

Fig. 13 Rope

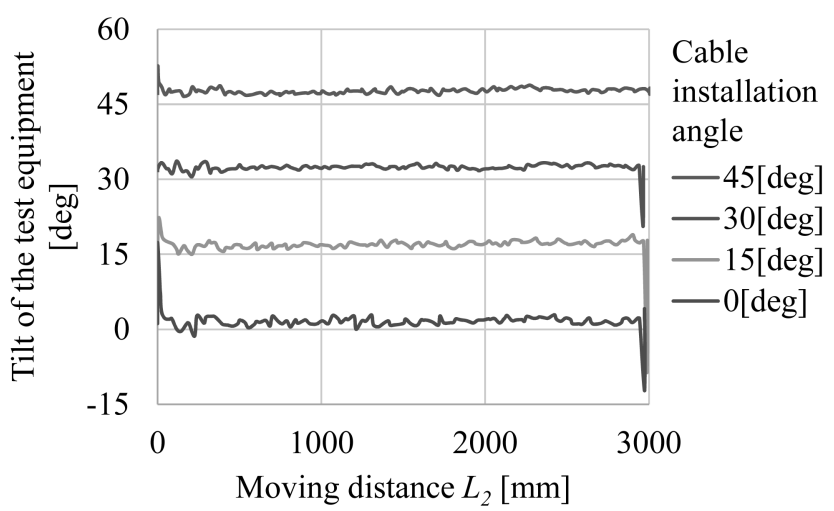

Fig. 14 Relationship between the moving distance $L_{2}$ and angle of the test equipment for each cable installation angle

袋に入れるペットボトルの本数で調整する．この状態で， $3[\mathrm{~m}]$ 移動させたときの駆動モー夕の回転数から得る距離 $L_{1}$ と実移 動距離計測用の受動輪の回転数から得る距離 $L_{2}$ を調べる.

Fig. 14 に, 受動輪の回転数から得た距離 $L_{2}$ と試験体の傾き との関係を電線の設置角度ごとに示す。おもりは外した状態で ある，試験体の傾きは，試験体の始動時と停止時以外は小さな 変動を伴いほぼ一定に推移している，小さな変動の原因は，撚 


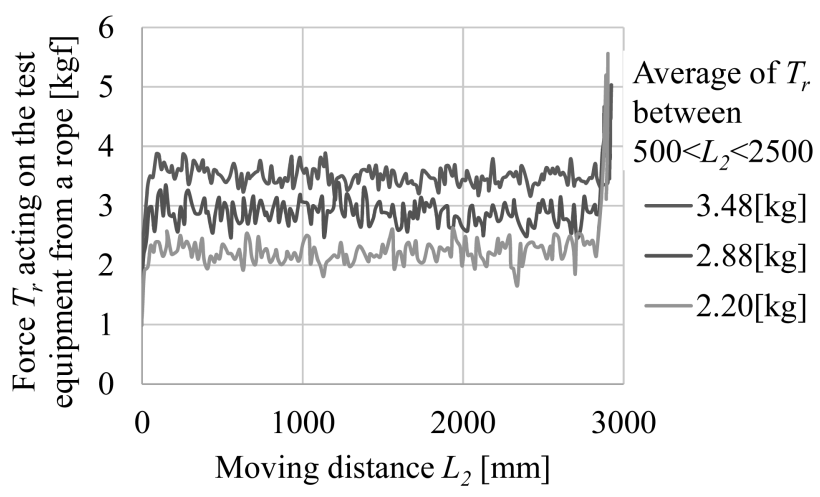

Fig. 15 Relationship between the moving distance $L_{2}$ and force acting on the test equipment from a rope for each weight

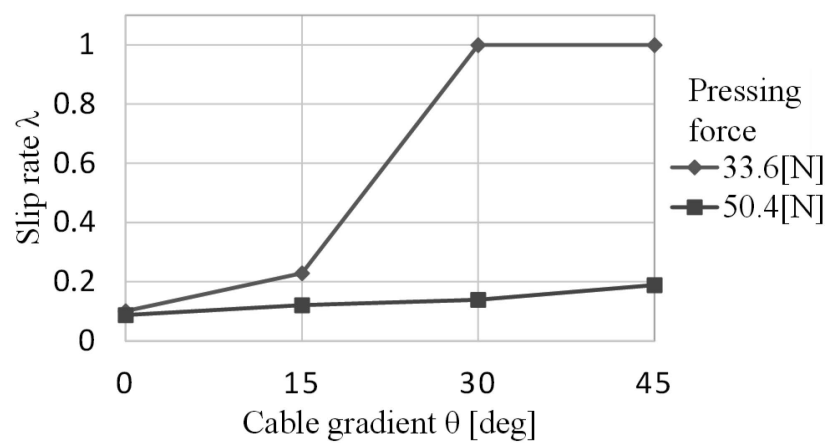

Fig. 16 Relationship between cable gradient $\theta$ and slip rate $\lambda$ showing the effect of pressing force under condition $P=33.6[\mathrm{~N}]$ and $50.4[\mathrm{~N}], T_{r}=35.3[\mathrm{~N}]$ and dry cable

り状のロープと滑車との接触抵抗が不均一であるためと考える. 電線設置角度より試験体の傾きが大きい理由は，おもりの重量 により滑車取り付け箇所の電線が下がることで，試験体移動範 囲の電線の勾配が増したためと考える，今回は，始動時と停止 時を抜かし，電線の設置角度を試験体の傾きとみなす.

Fig. 15 に，受動輪の回転数から得た距離 $L_{2}$ とロープから 試験体に作用する力の大きさ $T_{r}$ との関係を扑もりの重さごと に示す. $500<L_{2}<2,500$ での $T_{r}$ の平均值は, 3.48 [kgf], 2.88 [kgf]，2.20 [kgf] である. $T_{r}$ の值は試験体の始動時と停止 時以外は小さな変動を伴いほぼ一定に推移している．変動の原 因は，Fig. 14 と同様に撚り状のロープと滑車間の抵抗不均一の ためと考える.

\subsection{4 実験結果と考察}

Fig. 16 は，押付力の効果を示した電線勾配と滑り率との関 係である，滑り率の算出については， $500<L_{2}<2,500$ の範囲 における $L_{1}$ と $L_{2}$ を採用し, 3 回計測の平均值とした。いずれ の押付力においても電線勾配が増すにつれ滑り率も増すが，押 付力 33.6 [N] では電線勾配が 15 [deg] から 30 [deg] に至る範囲 で滑り率が大きく増加し，30 [deg] 以降では試験体は登坂でき なくなった。一方，押付力 $50.4[\mathrm{~N}]$ では電線勾配が増えても滑 り率は低く保たれ，登坂能力の低下は少なかった。このことか ら押付力の付与による登坂能力向上への効果は示された。なお 本実験では，押付力 $50.4[\mathrm{~N}]$ で電線勾配 $45[\mathrm{deg}]$ の登坂に成功 した.

一方で，本実験においては試験体の駆動輪の柔らかさも登坂 能力向上に寄与したと考える４.2.2 項で述べたとおり，本実験 で使用した試験体の駆動輪の硬度は電線のそれより低い。その

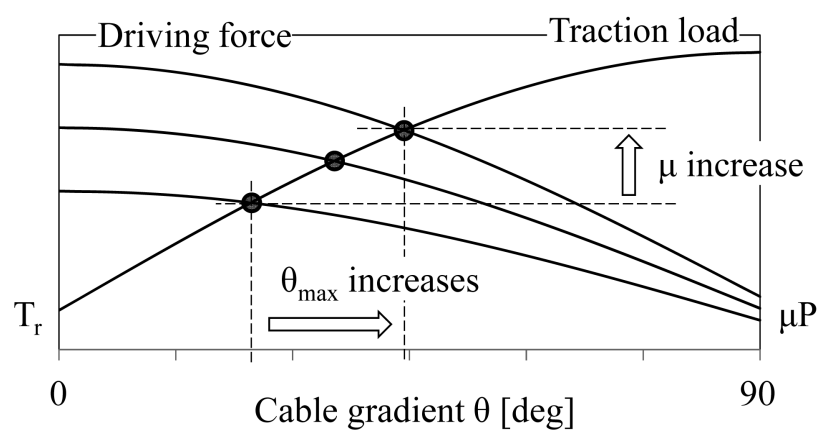

Fig. 17 Increase of the movable limit angle $\theta_{\max }$ due to increase of $\mu$

ことにより押付力の付与により駆動輪の電線との接触面が変形 し，駆動輪と電線との接触面積が増え，駆動輪・電線間の摩擦 力が増すと考える。このことは式（11）によると $\mu$ の值が増え ることを意味する．式（11）に基づいた $\mu$ にる $\theta_{\max }$ の変化 を表した模式図を Fig. 17 に示す。図中の丸印で示した駆動力 と搴引負荷との交点における電線勾配が $\theta_{\max }$ となる。 $\mu$ を増 すことで星引負荷を維持したまま駆動力のみ増やすことができ るため，結果 $\theta_{\max }$ は増加する，以上より，押付力の付与によ り $P$ だけではなく $\mu$ の増加という効果も得られる.

\section{5. まとめと今後の課題}

本研究では, RTD を用いた架空配電線路の電線架け替え工事 を確実に行えるように，最大登坂角度 $45[\mathrm{deg}]$ と実用性のある 大きさと重さを有するRTDの開発を目指し，現行の RTDの 観察とモデルの作成を行い，登坂限界を示すとともに，登坂能 力を向上させる方法として押付力の付与を提案し，実験により その妥当性を検証した。

現行の RTD を観察したところ，電線傾斜が 30 [deg] を超え たあたりで後輪が電線から離れ，その後，登坂限界に至ることを 確認した。車輪と電線との接触面積が半減することにより，グ リップカが不足したことが原因であると推察した.

現行の RTD 内部の機構と電線の幾何学的配置から, 電線勾 配が増しても重心は作用点である前輪を通る鉛直線上に位置し 続けるため，観察されたように後輪は電線から離れる現象が生 じることを示した.

現行の RTD のモデルを作成し，実験結果と理論曲線の一致， ならびに観察結果との整合から，このモデルの妥当性を示した. また，このモデルから登坂限界を示す理論式を導いた。

RTD の登坂能力向上の方法として, 後輪が電線から離れない ように，車輪と電線との押付力の付与を提案した。実験により， 押付力の付与は登坂能力向上に効果があることを実証した.

一方，電線の種別とサイズの違いにより駆動輪・電線間の押 付力 $P$ の值は変化し, また電線の表面状態（乾燥・湿潤）によ り $\mu$ の值は変化する. 電線の各要因における RTD の登坂能力 への影響については，まだ明らかにできていない。これらの解 明が今後の課題となる。

\section{参 考 文 献}

１］吉永潤一郎：“長径間ケーブル延線工法”, 平成 18 年度電気設備学会 全国大会予稿集，pp.315-318, 2006.

[2] 武本純平：“マルチコプタを活用した架空配電線工事に扔けるロープ 延線作業”, 日本ロボット学会誌, vol.36 no.8, pp.525-536, 2018.

[3] R.S. Goncalves and J.C.M. Carvalho: "Review and Latest Trends in Plobile Robots Used on Power Transmission Lines," 
Int. J. Adv. Robot. Syst., 2013, vol.10, 408:2013.

[ 4] 横井一広：“重心移動型フレームによる送電線自走機の登坂性能の向 上”，平成 29 年電気学会全国大会， $7-111,2017$.

[ 5] 今津篤志：“地上局とケーブルでつながれた複数のへリコプタによる障 害物回避飛行計画に関する研究”，日本ロボット学会誌，vol.36, no.1 pp.78-85, 2018

[6] 三輪章子：“テラメカニクスに基づく月・惑星探査ローバーの登坂性 能解析”，第 11 回ロボティクスシンポジア，2006.

[ 7 ] 山田泰之：“不整地を高速移動可能なはね付きクローラの登坂性能検 証”，日本ロボット学会誌，vol.35，no.2,pp.153-159, 2017.

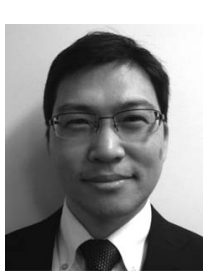

武本純平 (Jumpei Takemoto)

（株）関電工戦略技術開発本部技術開発ユニット技 術研究所勤務. 現在, 筑波大学大学院博士後期課程 に扔いて，ロボット技術を用いた架空配電線作業の 効率化の研究に携わっている.

(日本ロボット学会正会員)

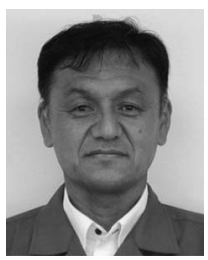

小林竜一 (Ryoichi Kobayashi)

（株）関電工東関東営業本部千葉支店社会インフラ 工事部配電線チーム所属.

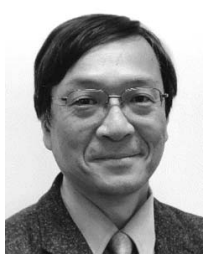

坪内孝司 (Takashi Tsubouchi)

1988 年 3 月筑波大学大学院博士課程工学研究科修 了, 工学博士. 宇都宮大学および東京大学助手を経 て, 1994 年筑波大学講師。2006 年 5 月より筑波大 学教授. 現在同大学システム情報系に所属. 屋内外 で働く移動・作業機械の自律化や移動ロボット技術 の産業転用などの研究開発に従事. 日本機械学会, 人工知能学会, 計測自動制御学会, IEEE の会員.

（日本ロボット学会正会員）
於保健一（Kenichi Oho）

(株) 関電工社会インフラ統轄本部施工品質ユニッ 卜技術企画部技術チーム所属.

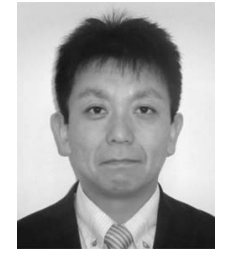

大田和健（Takeshi Ootawa）

(株) 関電工配電ユニット架空配電部架空配電線チー 厶所属. 